\title{
Traditional Selection Criteria of Ogaden Cattle in Pastoral and Agro Pastoral Production Systems and Its Implication to Resilience of the Breed in the Face of Climate Change in the Future
}

\author{
Yesihak Yusuf Mummed \\ School of Animal and Range Science, Haramaya University, Haramaya, Ethiopia \\ Email: yesihakyus@gmail.com
}

How to cite this paper: Mummed, Y.Y. (2019) Traditional Selection Criteria of Ogaden Cattle in Pastoral and Agro Pastoral Production Systems and Its Implication to Resilience of the Breed in the Face of Climate Change in the Future. Open Journal of Animal Sciences, 9, 355-366.

https://doi.org/10.4236/ojas.2019.93029

Received: June 7, 2019

Accepted: July 28, 2019

Published: July 31, 2019

Copyright $\odot 2019$ by author(s) and Scientific Research Publishing Inc. This work is licensed under the Creative Commons Attribution International License (CC BY 4.0).

http://creativecommons.org/licenses/by/4.0/

\begin{abstract}
Selecting for adapted livestock breeds that will produce at optimum in the anticipated climate change scenario is one way of sustaining the production system. Africa has accumulated indigenous knowledge to coping up with climate variability in the past. It is common practice to shift to livestock agriculture as climate becomes less predicted in Africa. Cattle contribute more than $80 \%$ of meat and milk in Ethiopia. The aim of this paper was to identify traditional selection criteria of Ogaden cattle breed in pastoral and agro pastoral production systems and suggest possible intervention strategies. Questionnaire survey was conducted in Wabeshebele Zone of Ethiopia, in three districts based on cattle population and accessibility on 126 households. The results of the study revealed that farmers preferred to own diversified livestock species to cope up with unpredicted climate. Milk production and body conformation were ranked first and second criteria in selecting female which were followed by adaptive characteristics such as coat color, fertility and longevity, respectively, while in male, adaptive characters such as hump size, body conformation, coat color and fertility were given priority over milk production. Selection criteria of cattle practiced in the society strongly favored adaptation and ability to perform in feed constraint environment in addition to meat, milk and fertility. However, the simplest reproductive biotechnology, AI, was rarely practiced in the study area. It was recommended that indigenous knowledge of the society on selection criteria of the cattle breed need to be integrated with utilization of assisted reproductive biotechnologies and on farm research innovations on the breed so far acquired in
\end{abstract}


any improvement program of the breed in the future.

\section{Keywords}

Ogaden Cattle, Traditional Selection Criteria, Adaptation

\section{Introduction}

Sustainable breeding program of livestock in the coming climate change scenario need to consider selection of breeds of animals that will be heat tolerant, feed efficient, disease and parasite resistant that will survive and produce at optimum satisfying preference of the society. The local populations in Sahel region which was prone to long and severe droughts, through their indigenous knowledge systems, have developed and implemented extensive mitigation and adaptation strategies that have enabled them reduce their vulnerability to past climate variability and change [1].

Community based breeding program was suggested an important approach in the genetic improvement programs to produce resilient livestock for the future. Pastoral and agro pastoral production system in the tropics had long standing indigenous livestock management practice as pastoral communities have been selecting for animals that produce and survive in their harsh environments. Developmental projects which did not take into consideration the culture of the society resulted in low participation and success rates [2].

The Ogaden cattle is one of tropical cattle breeds [3]. The breed has been evolved in arid and semi arid agro-ecological setup and widely distributed in the Ogaden area of the Somali region and bordering Eastern Hararghe [4] being owned by pastoral and agro pastoral societies. The breed has adapted to hot environments and has uniform plain white coat color with black shade around face.

Ex situ on farm characterization of Ogaden cattle revealed that the breed produced relatively higher milk yield which was estimate by weight-suckle-weight method than the local breed in the region [5] and yielded comparable milk yield to zebu cattle breed estimated by hand milking [6]. The average birth weight and weaning weight at six month were $21.5 \mathrm{~kg}$ and $91.7 \mathrm{~kg}$, respectively [7]. The researcher [7] further reported the good potential of the breed to be used for beef purpose. Average yearling and twenty-four months weight were reported 136.3 $\mathrm{kg}$ and $200.7 \mathrm{~kg}$, respectively, [8]. The same authors reported the good reproductive potential of the breed. Haemoglobin polymorphism of the breed was characterized and concluded that the population of breed is under Hardy-Weinberg equilibrium [4].

To properly design appropriate improvement strategy for the breed that will utilize innovation at research station which focused on meat, milk and reproductive performance improvement, it is important to identify the traditional selection criteria practiced for the breed in its in situ environment so that on farm 
research innovation will properly integrated with traditional selection criteria for the breed to yield at optimum in anticipated climate change scenario in the future. The objective of this study was to identify traditional selection criteria of Ogaden cattle in pastoral and agro pastoral production systems and suggest possible intervention strategies that will make the breed produce at optimum in the face of anticipated climate change scenario in the coming future.

\section{Materials and Methods}

\subsection{Descriptions of Study Area}

Wabeshebele Zone is located south-eastern portion of the Somali regional state of Ethiopia. It is one of the zone of Somali Regional States of Ethiopia which is characterized by high temperature, erratic rainfall and totally arid lowland. The zone is occupied by pastoral and irrigation based agro-pastoral population whose livelihood is mainly depending on range-livestock production. Wabeshebele River forms the Southern and Eastern boundaries of Gode district and bisects Kalafo and Mustahil towns and drain to Somalia. The landscape consists of dense shrub land, bush grassland and bare hills. The soil texture is sandy clay loam with alkaline $\mathrm{pH}$, high phosphorus and potassium, moderate sodium and cation exchange capacity and low organic carbon content [9].

\subsection{Data Collections}

Secondary information was obtained from Wabeshebele province and district agricultural offices on distribution and concentration of cattle in the areas. Based on the information Gode, Kalafo and Mustahil districts were selected based on population of cattle and accessibility. From each sampling districts, two sampling villages/kebeles were selected. Tribe leaders and elders have helped to select a total of 126 households for the survey based on the size, composition of cattle herd and experience with cattle husbandry. Selected households were informed of the objectives of research. They were offered veterinary service during the study period for their active participation in the survey. Data were collected over a period of five months (mid-September, 2014 to mid-February, 2015).

The studied variables were livestock production system, livestock holding, importance and purpose of cattle in the society, cattle breed preference and breeding practice, selection criteria of female and male cattle, and major production constraints.

\subsection{Statistical Analysis}

Data was analyzed using SAS version 9.2, 2008 software. Indices were developed to rank importance of the functions of specific variable. Indices were calculated using a formula: Index $=$ sum of (five times number of households ranked first + four times number of households ranked second + three times number of households ranked third + two times number of households ranked fourth + one times number of households ranked fifth) give for each parameter divided by 
sum of (five times number of households ranked first + four times number of households ranked second + three times number of households ranked third + two times number of households ranked fourth + one times number of households ranked fifth) for all parameters for those parameters ranked (1 to 5). The difference in frequency concerning specific variable of interest was tested and seen by chi-square test.

\section{Results and Discussion}

\subsection{Farming Systems Practiced in the Study Areas}

Table 1 shows farming systems practiced in the studied areas. About 30\% of respondents in the study area were pastorals while the rest about $70 \%$ agro-pastorals. The proportion of the two farming systems in the three study districts were significantly different $(\mathrm{p}<0.05)$. Kalafo district were exclusively agro-pastoral while in the other two districts pastoral and agro pastoral system the two systems relatively practiced fifty-fifty. Ethiopia's pastoral areas cover more than half of the country and raise excess stocks of cattle, sheep, goats and camels, providing a guaranteed supply base for domestic and external markets in spite of the harsh environment [10]. One of major mechanism of copping up with extreme weather with pastoral and agro pastoral society is moving from place to place looking for feed resource for their livestock. Pastoralists' nomadic mobility reduces the pressure on low carrying capacity grazing areas through the circular movement from the dry northern areas to the wetter southern areas of the Sahel. This system of seasonal movement represents a local type of traditional ranching management system of range resources [1]. If a herd is confined to one place, livestock numbers and productivity are limited by the scarcest resource in that particular place. A research report [1] indicated that nomadic cattle consistently out-perform sedentary cattle across a wide range of indicators such as calving interval, calving earlier, total herd mortality, calf mortality and meat production per breeding female. Productivity of pastoralist over settled ranch in terms of MJGE/ha/year and kg protein production/ha/year were reported in Semi-arid part of Africa [1]. This indicates the need to encourage continuity of these systems in the coming anticipated climate change scenario in the future.

Table 1. Farming systems practiced in the studied areas.

\begin{tabular}{|c|c|c|c|c|c|c|c|c|}
\hline \multirow{3}{*}{ Farming System } & \multicolumn{6}{|c|}{ District } & \multirow{2}{*}{\multicolumn{2}{|c|}{ Overall }} \\
\hline & \multicolumn{2}{|c|}{ Gode } & \multicolumn{2}{|c|}{ Kalafo } & \multicolumn{2}{|c|}{ Mustahil } & & \\
\hline & Freq. & $\%$ & Freq. & $\%$ & Freq. & $\%$ & Freq. & $\%$ \\
\hline Pastoral & 18 & 42.86 & - & - & 20 & 47.62 & 38 & 30.16 \\
\hline Agro-pastoral & 24 & 57.14 & 42 & 100 & 22 & 52.38 & 88 & 69.84 \\
\hline Total & 42 & & 42 & & 42 & & 126 & \\
\hline$x^{2}$ & & & & & 27.212 & & & \\
\hline P-value & & & & & $<0.0001$ & & & \\
\hline
\end{tabular}

$\mathrm{P}<0.05$ shows significant difference. 


\subsection{Livestock Holding in the Study Areas}

Mean livestock holding per household in the study areas are presented in Table 2. The size of livestock holding per household were significant different among the three districts with large size of livestock in Mustahil (79.1) followed by Gode (62.8) district. The smaller size of livestock in Kalafo district (32.23) compared to the other two districts might be due to the engagement of the farmers in crop cultivation activity as agro pastoral system was exclusively practiced in this district. Similarly, relatively lower numbers of cattle, goats and sheep were present in Kalafo than the other two districts. Pastoral and agro-pastoral system in tropical Africa are known to accommodate diversified species of livestock as a means of coping mechanism against unpredicted weather in the region. During drought periods, pastoralists and agro-pastoralists change from cattle (Bos) to sheep (Capra) and goat (Capra) husbandry as the feed requirements of the later is less than the former [11].

\subsection{Importance of Livestock in the Study Areas Based on Income Generation}

Importance of livestock based on income generation for the farmer in the study area are presented in Table 3. The results of the study revealed that there was significant difference on sell of cow milk, donkey draught power and sell of camel milk between districts $(\mathrm{p}<0.05)$ but no significant difference was observed between districts on sell of goat milk and sell of sheep milk ( $p>0.05)$. The highest index value obtained for sale of cow milk as a means of income generation to the farmers in the three districts indicate the importance of cattle as a means of daily income in the farmers in the studied areas. Milk from goats and sheep might not left for sale beyond home consumption in the three districts.

\subsection{Breed Preference and Cattle Breeding Practices}

Cattle breeding practice in the study areas are presented in Table 4 . Most of the respondents $(>83 \%)$ in the study areas preferred to keep Ogaden cattle breed.

Table 2. Mean livestock holding per household in the study areas.

\begin{tabular}{cccccccc}
\hline \multirow{2}{*}{ Livestock Species } & $\mathrm{N}$ & \multicolumn{2}{c}{ Gode } & \multicolumn{2}{c}{ Kalafo } & \multicolumn{2}{c}{ Mustahil } \\
\cline { 3 - 8 } & & Mean & SD & Mean & SD & Mean & SD \\
\hline Cattle & 42 & $18.40^{\mathrm{b}}$ & 2.83 & $15.90^{\mathrm{c}}$ & 3.17 & $24.45^{\mathrm{a}}$ & 4.53 \\
Goat & 42 & $20.66^{\mathrm{b}}$ & 3.00 & $7.42^{\mathrm{c}}$ & 1.41 & $28.97^{\mathrm{a}}$ & 5.08 \\
Sheep & 42 & $19.26^{\mathrm{b}}$ & 2.45 & $8.78^{\mathrm{c}}$ & 1.67 & $26.83^{\mathrm{a}}$ & 4.46 \\
Camel & 42 & $4.47^{\mathrm{a}}$ & 1.32 & $0.00^{\mathrm{b}}$ & 0 & $0.00^{\mathrm{b}}$ & 0 \\
Donkey & 42 & $1.11^{\mathrm{b}}$ & 0.32 & $1.54^{\mathrm{a}}$ & 0.50 & $1.04^{\mathrm{b}}$ & 0.21 \\
Total & 42 & $62.80^{*}$ & 90.03 & $32.23^{*}$ & 6.27 & $79.1^{*}$ & 13.44 \\
\hline
\end{tabular}

Means with different letter across the rows are significantly different; $\mathrm{N}=$ number of observation; $\mathrm{ns}=$ nonsignificant; ${ }^{*}$ significant at $\mathrm{P}<0.05$. 
Table 3. Importance of livestock based on income generating for the farmer.

\begin{tabular}{|c|c|c|c|c|c|c|c|}
\hline \multirow{2}{*}{ District } & \multirow{2}{*}{$\begin{array}{l}\text { Daily income generating } \\
\text { livestock product }\end{array}$} & \multicolumn{6}{|c|}{ Rank } \\
\hline & & 1 & 2 & 3 & 4 & 5 & Index \\
\hline \multirow[t]{5}{*}{ Gode } & Sell of cow milk & 39 & 3 & 0 & 0 & 0 & 0.33 \\
\hline & Rent of donkey & 3 & 39 & 0 & 0 & 0 & 0.27 \\
\hline & Sell of goat milk & 0 & 0 & 26 & 16 & 0 & 0.17 \\
\hline & Sell of sheep milk & 0 & 0 & 16 & 26 & 0 & 0.16 \\
\hline & Sell of camel milk & 0 & 0 & 0 & 0 & 42 & 0.07 \\
\hline \multirow[t]{5}{*}{ Kalafo } & Sell of cow milk & 29 & 13 & 0 & 0 & 0 & 0.34 \\
\hline & Rent of donkey & 13 & 29 & 0 & 0 & 0 & 0.31 \\
\hline & Sell of goat milk & 0 & 0 & 30 & 12 & 0 & 0.19 \\
\hline & Sell of sheep milk & 0 & 0 & 12 & 30 & 0 & 0.16 \\
\hline & Sell of camel milk & 0 & 0 & 0 & 0 & 0 & 0 \\
\hline \multirow[t]{5}{*}{ Mustahil } & Sell of cow milk & 42 & 0 & 0 & 0 & 0 & 0.36 \\
\hline & Rent of donkey & 0 & 42 & 0 & 0 & 0 & 0.29 \\
\hline & Sell of goat milk & 0 & 0 & 31 & 11 & 0 & 0.19 \\
\hline & Sell of sheep milk & 0 & 0 & 11 & 31 & 0 & 0.16 \\
\hline & Sell of camel milk & 0 & 0 & 0 & 0 & 0 & 0 \\
\hline \multirow[t]{6}{*}{ Significance between districts } & & & $x^{2}$ & & & P-value & \\
\hline & Sell of cow milk & & 19.744 & & & $<0.0001$ & \\
\hline & Rent of donkey & & 19.744 & & & $<0.0001$ & \\
\hline & Sell of goat milk & & 1.547 & & & 0.461 & \\
\hline & Sell of sheep milk & & 1.547 & & & 0.461 & \\
\hline & Sell of camel milk & & 125.00 & & & $<0.0001$ & \\
\hline
\end{tabular}

$\mathrm{P}<0.05$ shows the significant difference.

Table 4. Cattle breeding practice in the study areas.

\begin{tabular}{|c|c|c|c|c|c|c|c|c|c|}
\hline \multirow{2}{*}{\multicolumn{2}{|c|}{ Cattle breeding practice }} & \multicolumn{6}{|c|}{ District } & \multirow{3}{*}{$x^{2}$} & \multirow{3}{*}{ P-value } \\
\hline & & \multicolumn{2}{|c|}{ Gode } & \multicolumn{2}{|c|}{ Kalafo } & \multicolumn{2}{|c|}{ Mustahil } & & \\
\hline & & $\mathrm{N}$ & $\%$ & $\mathrm{~N}$ & $\%$ & $\mathrm{~N}$ & $\%$ & & \\
\hline \multirow[t]{3}{*}{ Breed preference } & Ogaden cattle only & 36 & 85.71 & 35 & 83.33 & 37 & 88.10 & 0.385 & 0.825 \\
\hline & Other local cattle & 0 & 0 & & 0 & & 0 & & \\
\hline & Ogaden and other breed & 6 & 14.29 & 7 & 16.67 & 5 & 11.90 & & \\
\hline \multirow[t]{2}{*}{ Castration } & Yes & & 0 & & 0 & & 0 & 0.000 & 1.000 \\
\hline & No & 42 & 100 & 42 & 100 & 42 & 100 & & \\
\hline \multirow[t]{2}{*}{ Heat detection method } & Observation of behavioral change & & 100 & & 100 & & 100 & 0.000 & 1.000 \\
\hline & Use of teaser male/castrated & & 0 & & 0 & & 0 & & \\
\hline \multirow[t]{2}{*}{ Mating } & Non-seasonal & 42 & 100 & 42 & 100 & 42 & 100 & 0.000 & 1.000 \\
\hline & AI service & & 0 & & 0 & & 0 & & \\
\hline
\end{tabular}

$\mathrm{N}=$ number of observation; $\mathrm{P}<0.05$ shows the significant difference. 
This might be due to the awareness already exist in the society about the adaptation of the breed to their specific environment which made them assumed that it was important for them. The result of the survey revealed that the absence of the practice of castration, use of teaser bulls to detect heat, AI service and controlled mating. This indicated the absence of breed improvement extension activities in the study areas. General concern on the disappearing of genetic variation in East African cattle was reported which might be caused by the absence of breed development programs in the region [12].

\subsection{Purpose of Keeping Cattle in the Study Areas}

Purpose of keeping female and male cattle in the study areas are presented in Figure 1. Females were primarily kept for milk production while males were primarily kept as a ransom for conflict resolution in the study areas. In the present study, the survey indicated that selection for milk production was made from maternal side only. However, selection for meat purpose was made from both maternal and paternal side. Probably, tradition long selection program for beef that was practiced in the in situ production system might contribute for reported [7] [8] [13] potential of the breed for beef purpose. The purpose of the breed as bride gift, conflict resolution and slaughter during ceremony indirectly favored the selection of the breed for beef purpose. The breed was reported to produce relatively higher milk yield estimate by weight-suckle-weight method than the local breed in the region [5] and yielded comparable milk yield to zebu cattle breed estimated by hand milking [6] at research station at Harmaya University.

\subsection{Selection Criteria for Female and Male Cattle in the Study Areas}

Selection criteria for female and male cattle in the study areas are presented in Figure 2. Milk production was the main criteria in selecting female which were followed by some adaptive characteristics such as conformation, coat color, fertility and longevity. In case of males, adaptive characters such as hump size, body conformation, coat color and fertility were given priority over milk production. Hump is a means to store fat against unpredicted feed resource and a means of better heat transfer. Selection for better body conformation in both male and female sides might suggest the understanding of the farmers on the
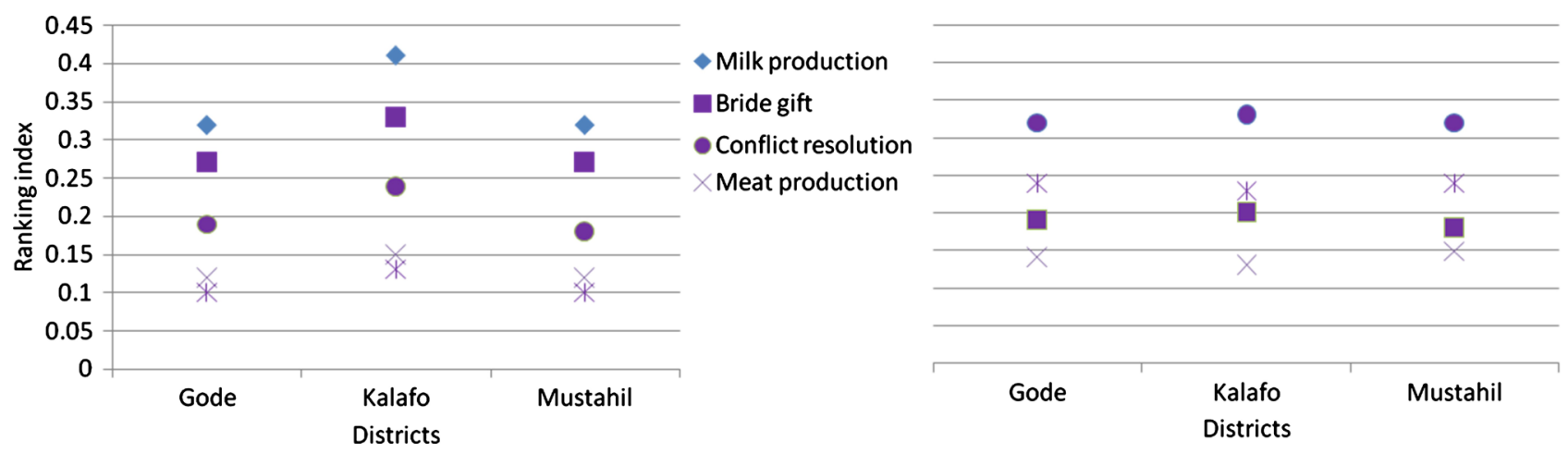

Figure 1. Purpose of keeping female (Left) and male (right) cattle. 


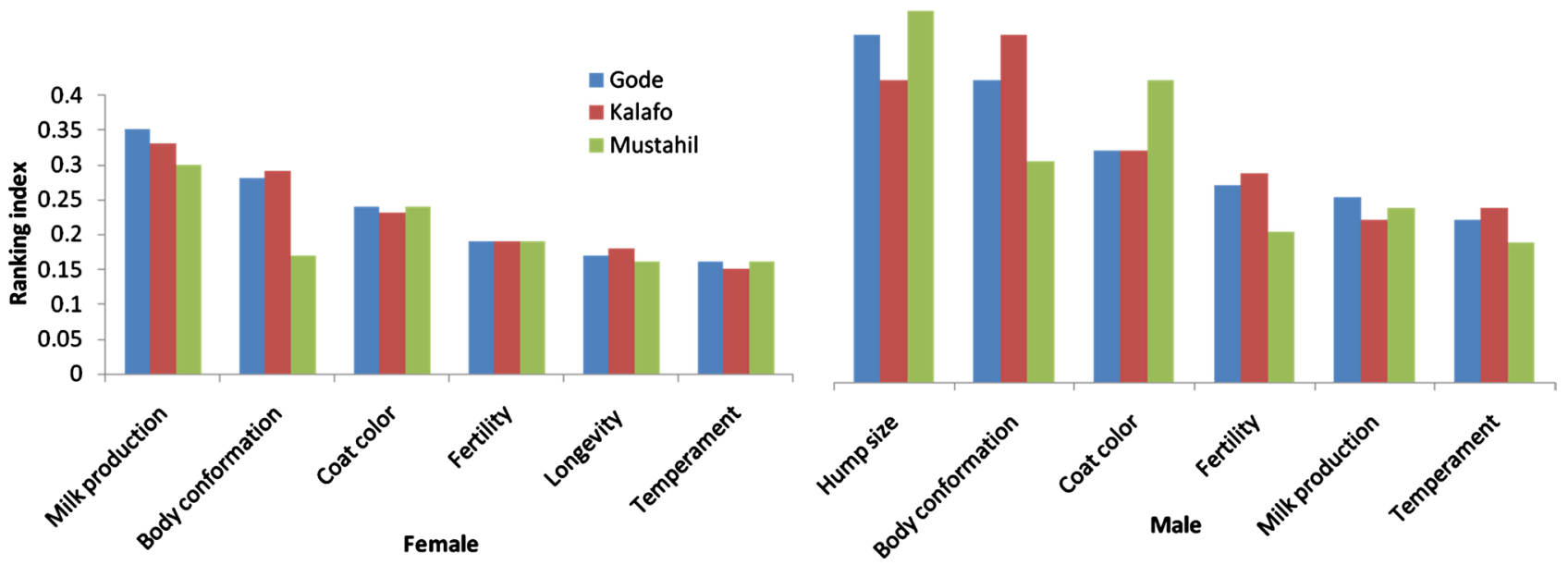

Figure 2. Selection criteria for female and male cattle in the study areas.

importance of selecting for animals that can produce optimum muscle in the feed scarce environment. Despite the importance of milk for pastoral and agro-pastoral society, selection in male side was less practiced. This further confirms the importance of adaptive characters of livestock in pastoral societies. The importance of the female for conflict resolution, ceremonial slaughter and gift during marriage might favored indirectly the selection for beef and milk purpose despite the responses of respondent indicated less attention given to meat production purpose of the breed. The meat production might referred to selling for beef purpose which might not as such practiced unless money is required by the family to cover some emergency expense, to cover medical and school expense of the children. After all having large size of herd irrespective of production level was considered as prestige in the pastoral society. The second and third most important selection criteria for females were coat color and hump size which might be associated with selection for adaptive character of the breed for arid environment in the region. The white gray coat might be a means of adaptation to arid climate to reflect sunrays while large size hump implied for a means of storing fat for unpredicted arid environment dominated the region. Selecting for adaptive character, which is considered as a new approach in current breeding program, had been practiced for long time in the past by pastoral and agropastoral society in tropical part of Africa. Research endeavor so far took place in research stations for improvement of Ogaden cattle breed concentrated on productive and reproductive performance of the breed [5] [6] [7] [8] [13]. Extending research output of Ogaden cattle produced at research station to pastoral and agro-pastoral society need to be combined with the indigenous knowledge so far accumulated on adapting the breed to its native environment by the society so that the breed will be resilient in the coming climate change scenario. After all, community based breeding program was suggested an important approach in the genetic improvement programs to produce resilient livestock for the future. Pastoral society in arid part of tropical Africa were prone to long and severe droughts. They have developed and implemented extensive mitigation and adap- 
tation strategies, through their indigenous knowledge systems, that have enabled them reduce their vulnerability to past climate variability and change [1]. The success rates developmental projects which did not take into consideration relevant indigenous knowledge of the society in tropics part of Africa was low participation [2].

\subsection{Major Production Constraints in the Study Area}

Major constraints in the study area are presented in Figure 3. Feed constraint was the major and equally important constraints in the study areas with index value of 0.30 . The land use system which was considered by respondents as the least among other constraints in the study area could also contributed to the feed shortage. Conflicts between farmers in adjacent region over feed and water resource were common phenomena in pastoral and agro pastoral areas as livestock owners move from place to place in search of feed for their livestock, particularly, during dry season. As grazing land belongs to the community as a whole, each and every farmer had equal right of using the resource for their animals, irrespective of concern for overgrazing and degradation. The response from the respondents revealed that farmers know the land use system practiced in the study areas contributed to feed problems. Land and legislation reforms that recognize pastoralists' rights to their own lands and resources were suggested necessary strategy to continue and increase the production of valuable animals and animal products and to reduce conflict and insecurity in pastoral area [10]. The poor infrastructure reported by the farmers might have contributed to the poor health care and AI services. As the diseases and parasites were one of the major constraints for the breed in the studied areas, breeding strategy that will be developed for the breed in similar environment need to consider selection for diseases and parasites resistance in the future in addition to the traits of adaptation, feed efficiency, production and reproduction which were considered by the society in the study areas.

\subsection{Adaptive Features of Ogaden Cattle Breed}

Table 5 shows adaptive feature of female and male Ogaden cattle in the study

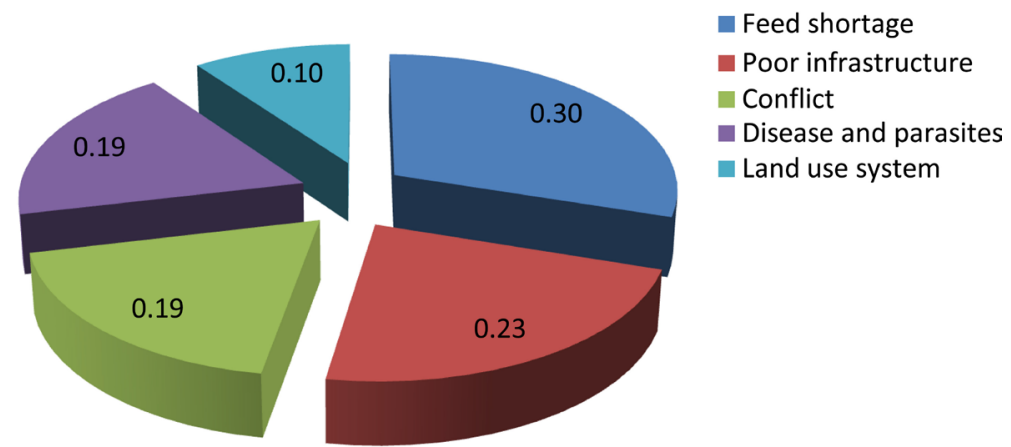

Figure 3. Major constraints againest cattle production in the studied areas based on ranking index. 
Table 5. Adaptive feature of Ogaden cattle reflected by response in milk yield and body condition to change in feed availability and management.

\begin{tabular}{|c|c|c|c|c|c|c|c|c|c|c|c|c|c|}
\hline \multirow{3}{*}{ Factors } & \multirow{3}{*}{ Response } & \multicolumn{4}{|c|}{ Gode } & \multicolumn{4}{|c|}{ Kalafo } & \multicolumn{4}{|c|}{ Mustahil } \\
\hline & & \multicolumn{2}{|c|}{ Female } & \multicolumn{2}{|c|}{ Male } & \multicolumn{2}{|c|}{ Female } & \multicolumn{2}{|c|}{ Male } & \multicolumn{2}{|c|}{ Female } & \multicolumn{2}{|c|}{ Male } \\
\hline & & No. & $\%$ & No. & $\%$ & No. & $\%$ & No. & $\%$ & No. & $\%$ & No. & $\%$ \\
\hline \multirow{3}{*}{$\begin{array}{l}\text { Decrease/increase in } \\
\text { availability of feed } \\
\text { resource }\end{array}$} & $\begin{array}{l}\text { Rapid decrease in milk yield/ } \\
\text { immediate increase when adequate }\end{array}$ & 1 & 2.38 & & & 1 & 2.38 & & & 1 & 2.38 & & \\
\hline & $\begin{array}{l}\text { Slow decrease in milk yield/slow } \\
\text { increase when adequate }\end{array}$ & 3 & 7.14 & & & 4 & 952. & & & 5 & 11.90 & & \\
\hline & $\begin{array}{l}\text { Rapid decrease in milk yield; slow } \\
\text { increase when adequate }\end{array}$ & 1 & 2.18 & & & 2 & 4.76 & & & 1 & 2.38 & & \\
\hline $\begin{array}{l}\text { Decrease/increase in } \\
\text { availability of feed } \\
\text { resource }\end{array}$ & $\begin{array}{l}\text { Slow decrease in body condition/ } \\
\text { rapid increase when adequate }\end{array}$ & 25 & 64.29 & 17 & 80.95 & 25 & 59.52 & 16 & 76.19 & 34 & 80.95 & 11 & 61.11 \\
\hline \multirow{2}{*}{$\begin{array}{l}\text { Mature cattle } \\
\text { manifested disease } \\
\text { condition in lifetime }\end{array}$} & Yes & 9 & 21.43 & 5 & 23.81 & 14 & 33.33 & 1 & 4.76 & 13 & 30.95 & 4 & 22.22 \\
\hline & No & 33 & 78.57 & 16 & 76.19 & 28 & 66.67 & 20 & 95.24 & 29 & 69.05 & 14 & 77.78 \\
\hline \multirow{3}{*}{$\begin{array}{l}\text { Decline in } \\
\text { management and } \\
\text { welfare }\end{array}$} & Highly sensitive & 0 & 0 & & & 0 & 0 & & & 0 & 0 & & \\
\hline & Moderately respond & 0 & 0 & 3 & 14.29 & 0 & 0 & 7 & 33.33 & 0 & 0 & 2 & 11.11 \\
\hline & Do not respond unless extreme & 42 & 100 & 18 & 85.71 & 42 & 100 & 14 & 66.67 & 42 & 100 & 16 & 89.89 \\
\hline
\end{tabular}

areas. Most of the respondents in the study areas reported that milk yield was decreasing slowly as feed availability started decreasing (more than $83.33 \%$ ) and was increasing rapidly $(64.29 \%, 59.52 \%$ and $80.95 \%$ Gode, Kalafo and Mustahil, respectively) when feed resource was adequate. Moreover, most respondents reported that change body condition was decreasing slowly as the availability of feed become scarce and body condition of cattle was increasing rapidly when it was adequate for both mature males and females. Most of the respondents responded that mature female and male animals didn't shown the disease condition most of the time in their lifetime. Most of the respondents in study areas (>66.67) responded that their cattle did not respond to decline in management and welfare unless conditions were extreme.

As shown on Figure 2, white coat color was ranked third in selection criteria of the breed. The breed was reported to have white to white gray color [4]. Coat color was one of the important morphological traits which impart adaptive ability to heat stressed livestock [14]. Light-/white colored coats advantageous as it reflects $50 \%$ to $60 \%$ of direct solar radiation compared with the dark-coloured coat of animals [15]. In case of male of the cattle breed, as already stated the hump was ranked first in the selection criteria. Most zebu/tropical cattle were known for their hump. Large size hump implied for a means of storing fat for against unpredicted feed resource in arid environment. This can also be consi- 
dered as a good adaptive future of the breed for tropical environment. In general, morphological parameter of the breed indicated that it has good adaptive future in arid environment. However, physiological, endocrine and biochemical response to stress need to be evaluated.

\section{Conclusion and Recommendations}

Pastoral and agro-pastoral system practiced in the studied areas diversified livestock species against unpredicted future. Importance of livestock as income generation, preference of the farmer for the existing local breed and purpose of keeping cattle shaped the selection criteria for the existing cattle breed. Selection criteria practiced in the society favored multipurpose cattle i.e. meat, milk, fertility, adaptation to the environment and ability of the cattle to efficiently utilize the existing sever feed shortage. The indigenous knowledge of pastoral and agro-pastoral society that already incorporated adaptation and feed efficiency in their selection program suggested that to cope up the anticipated climate change in the future, it is not only important to preserve the cattle genetic resources but also indigenous knowledge of the society so that it will contribute as an experience to be shared in the future. Despite the importance of reproductive biotechnologies such as AI to improve productive and reproductive performance of cattle breed, there was no practice of exploiting the technology in the study areas. It is recommended that breeding strategy that will be developed for Ogaden cattle in these production systems need to consider technologies that fasten the improvement of traits of adaptation, feed efficiency, milk and meat production, and traits of diseases and parasites resistance already favored by the society in the traditional selection practices. Opportunities available on assisted reproduction technologies need to be integrated with indigenous traditional knowledge so that resilient Ogaden cattle breed will evolve soon against heat load, feed shortage, diseases and parasite burden that will anticipated in the coming climate change scenario.

\section{Acknowledgements}

The author wants to express his gratitude to Mr. Asefa Masha, for his assistance in collecting data in the study areas. Haramaya University has financially supported the study. Pastoral and agro pastoral society in Gode, Kalafo and Mustahil districts of Wabishebelle zone need appreciation for their cooperation during data collection. Last but not least, Bureau of Agriculture at provincial and district level of Wabishebelle zone were kindly acknowledged in this research.

\section{Conflicts of Interest}

The author declares no conflicts of interest regarding the publication of this paper.

\section{References}

[1] Nyong, A., Adesina, F. and Osman Elasha, B. (2007) The Value of Indigenous 
Knowledge in Climate Change Mitigation and Adaptation Strategies in the African Sahel. Mitigation and Adaptation Strategies for Global Change, 12, 787-797. https://doi.org/10.1007/s11027-007-9099-0

[2] Nyong, A.O. and Kanaroglou, P.S. (1999) Domestic Water Demand in Rural SemiArid North-Eastern Nigeria: Identification of Determinants and Implications for Policy. Environment and Planning A, 34, 145-158.

[3] EBI (Ethiopian Biodiversity Institute) (2016) Ethiopian National Strategy and Plan of Action for Conservation and Utilization of Animal Genetic Resources. Ethiopian Biodiversity Institute (EBI), Addis Ababa. http://www.ebi.gov.et

[4] Pal, S.K. and Mummed, Y.Y. (2014) Investigation of Haemoglobin Polymorphism in Ogaden Cattle. Veterinary World, 7, 229-233.

https://doi.org/10.14202/vetworld.2014.229-233

[5] Mummed, Y.Y. (2012) Milk Yield Estimation of Ogaden Cattle Breed Based on Methods of Weigh-Suckle-Weigh and Calves' Growth. Tropical Animal Health and Production, 44, 785-790. https://doi.org/10.1007/s11250-011-9968-0

[6] Yusuf, Y. (2011) Milk Yield of Ogaden Cattle at Haramaya University, Eastern Ethiopia. Journal of Livestock Research for Rural Development, 23, 6. http://www.lrrd.org/lrrd23/6/yusu23125.htm

[7] Mummed, Y.Y. (2013) Correlation between Milk Suckled and Growth of Calves of Ogaden Cattle at One, Three and Six Months of Age, East Ethiopia. SpringerPlus, 2, 302. https://doi.org/10.1186/2193-1801-2-302

[8] Mekuriaw, G., Workneh, A. and Hegde, P.B. (2009) Growth and Reproductive Performance of Ogaden Cattle at Haramaya University, Ethiopia. EJAP, 9, 13-38.

[9] Berhanu, S. (2014) Response of Sesame (Sesame indicum L.) Variety to Nitrogen Fertilizer under Irrigation at Gode, Somali Regional State. M.Sc. Thesis. Haramaya University, Haramaya.

[10] Little, P.D., Behnke, R., McPeak, J. and Gebru, G. (2010) Future Scenarios for Pastoral Development in Ethiopia, 2010-2025. Report Number 2 Pastoral Economic Growth and Development Policy Assessment, Ethiopia.

[11] Oba, G. (1997) Pastoralists' Traditional Drought Coping Strategies in Northern Kenya. A Report for the Government of the Netherlands and the Government of Kenya, Euroconsult BV, Arnheim and Acacia Consultants Ltd., Nairobi.

[12] Jahnke, H.E. (1982) Livestock Production Systems and Livestock Development in Tropical Africa. KWV, Kiel, 253 p.

[13] Mekasha, Y., Urge, M., Kurtu, M.Y. and Bayissa, M. (2011) Effect of Strategic Supplementation with Different Proportion of Agro-Industrial Byproducts and Grass Hay on Body Weight Change and Carcass Characteristics of Tropical Ogaden Bull (Bosindicus) Grazing Native Pasture. African Journal of Agricultural Research, 6, 825-833.

[14] Sejian, V., Bhatta, R., Gaughan, J.B., Dunshea, F.R. and Lacetera, N. (2018) Review: Adaptation of Animals to Heat Stress. Journal of Animal, 12, s431-s444. https://doi.org/10.1017/S1751731118001945

[15] McManus, C.M., Paludo, G.R., Louvandini, H., Gugel, R., Sasaki, L.C.B. and Paiva, S.R. (2009) Heat Tolerance in Brazilian Sheep: Physiological and Blood Parameters. Tropical Animal Health Production, 41, 95-101. https://doi.org/10.1007/s11250-008-9162-1 